\title{
THE MEDIATING ROLE OF CORPORATE ENTREPRENEURSHIP FOR EXTERNAL ENVIRONMENT EFFECTS ON PERFORMANCE
}

\author{
Claudine Kearney ${ }^{1}$, Robert D. Hisrich ${ }^{2}$, Bostjan Antoncic ${ }^{3}$ \\ ${ }^{1}$ Michael Smurfit Graduate Business School, UCD, University College Dublin, \\ Carysfort Avenue, Blackrock, Dublin, Ireland \\ ${ }^{2}$ Thunderbird School of Global Management, TSGM, 1 Global Place, Glendale, \\ AZ 85306-6000, U.S.A. \\ ${ }^{3}$ Faculty of Economics University of Ljubljana, UL EF, Kardeljeva pl. 17, \\ SI-1000 Ljubljana, Slovenia \\ E-mails: ${ }^{1}$ Claudine.Kearney@thunderbird.edu; ${ }^{2}$ robert.hisrich@thunderbird.edu; \\ 3b.antoncic@gmail.com (correspondingauthor)
}

Received 19 January 2012; accepted 18 July 2012

\begin{abstract}
A model is proposed that tests the antecedents and the mediating effect of corporate entrepreneurship on the external environment-performance relationship within private and public sector organizations. Hypotheses were tested using data from a sample of chief executive officers in 51 private sector organizations in the United States, 141 private sector organizations in Slovenia and 134 public sector state and semi-state enterprises in Ireland. Data was analyzed using hierarchical regression analysis. The results show that dynamism and munificence effects on performance are mediated by an organization's corporate entrepreneurship in the private sector and munificence effects on performance are mediated by an organization's renewal in the public sector and that renewal must be in place to maximize the effect of munificence on performance. The results support a model that incorporates an extensive and diverse literature into a single model and helps illuminate similarities and differences of corporate entrepreneurship between the private sector and the public sector. The study shows that an integrative model and the interplay among the constructs yields new insights unavailable to single and focused approaches. It offers new insights about corporate entrepreneurship, not only as a discrete pursuit, but also as a construct that shapes and extends organizational performance.
\end{abstract}

Keywords: corporate entrepreneurship, private and public sector organizations, external environment, organizational performance, mediational model.

Reference to this paper should be made as follows: Kearney, C.; Hisrich, R. D.; Antoncic, B. 2013. The mediating role of corporate entrepreneurship for external environment effects on performance, Journal of Business Economics and Management 14(Supplement 1): S328-S357.

JEL Classification: L26, L33, L3.

\section{Introduction}

While researchers have diversely conceptualized the dimensions of corporate entrepreneurship, it is generally defined as a set of organizational level activities that focus on the discovery and pursuit of new opportunities through acts of venturing, renewal, 
innovation, risk taking and proactivity (e.g., Miller 1983; Guth, Ginsberg 1990; Zahra, Covin 1995; Sharma, Chrisman 1999; Antoncic, Hisrich 2001; Morris et al. 2008). Despite the inherent risks associated with the pursuit of corporate entrepreneurship, it is generally asserted that organizations can adapt and change to meet the demands of new market imperatives by pursuing corporate entrepreneurship (e.g., Ireland et al. 2009).

Corporate entrepreneurship has increasingly been recognized as one path to high levels of organizational performance (Morris et al. 2008). Organizations that exhibit corporate entrepreneurship are generally recognized as dynamic, flexible entities preparing, or prepared to take advantage of new business opportunities when they emerge (Morris et al. 2008). In changing and increasingly dynamic environments, organizations must identify entrepreneurial opportunities that will generate greater performance outputs. In general, corporate entrepreneurship flourishes in established firms when individuals are free to pursue actions and initiatives that are novel to the organization (Goodale et al. 2010). Nonetheless, the factors that drive entrepreneurial activity in established organizations may not result in superior performance at the organizational level if the organization is not adapting to the external environment. For corporate entrepreneurship to enhance organizational performance, it must adapt to the external environment. Research using various methods and models has indicated that the external environment has a strong influence on the existence and effectiveness of entrepreneurial activity (Covin, Slevin 1991). Therefore, the ability of those internal factors that drive corporate entrepreneurship activity to enhance performance is likely contingent upon the organization's ability to judiciously adapt to its external environment.

While many studies have examined the direct relationship between corporate entrepreneurship and performance (e.g., Zahra, Covin 1995; Dess et al. 2003, Kearney et al. 2010), a few studies have aimed to identify the contingencies in which this relationship may emerge (e.g., Zahra, Covin 1995; Antoncic, Hisrich 2001). Research has also been conducted on the organization's external environment as an antecedent of corporate entrepreneurship (e.g., Miller 1983; Khandwalla 1987; Covin, Slevin 1991; Zahra 1991, 1993; Antoncic, Hisrich 2001). However, there is a limited level of theory and empirical findings about the mediating role of corporate entrepreneurship for external environment effects on performance in the private sector, and no research of this nature has been undertaken in the public sector. Organizations should instigate entrepreneurial strategies to the environment that surrounds them. An environment poses challenges and opportunities on which organizations can try to capitalize in an entrepreneurial way. In an effort to enrich theoretical explanations of the association between corporate entrepreneurship and organizational performance, this study proposes a deeper explanation based on the premise that corporate entrepreneurship maximizes the external environment - performance relationship.

Beyond directly examining the impact of corporate entrepreneurship on performance, this study demonstrates that the external environment's influence on performance is enhanced through corporate entrepreneurship. The mediational model is tested using data from the chief executive officers (CEOs) of a sample of 51 medium to large private sector organizations in the United States, 141 small to medium private sector organizations in Slovenia and 134 public sector state and semi-state enterprises in Ireland. 
Findings suggest that dynamism and munificence effects on performance are mediated by organization's corporate entrepreneurship in the private sector. Whereas munificence effects on performance are mediated by organization's renewal in the public sector and that renewal must be in place to maximize the effect of munificence on performance.

This study contributes to research by developing a mediational model that tests a theoretical explanation of the external environment - performance relationship. It draws on theoretical insights from private and public sector literature on corporate entrepreneurship to explain how adapting to the external environment leads to improved firm performance by maximizing the effect of the organization's corporate entrepreneurial activities. In doing so, it offers new insights about corporate entrepreneurship, not only as a discrete pursuit, but also as construct that shapes and extends organizational performance. It contributes to the literature by studying these effects in the context of private and public sector organizations as part of a multi-nation study, as prior studies of corporate entrepreneurship have predominantly focused on large private sector organizations in the United States.

\section{Theoretical background and model tested}

This study's core insight - that through the influence of key external environment dimensions, corporate entrepreneurship may have important effects on performance. The general external environment construct and its impact on entrepreneurial activity has been the subject of ongoing discussion among researchers (e.g., Miller 1983; Khandwalla 1987; Covin, Slevin 1991; Zahra 1991, 1993; Antoncic, Hisrich 2001) mainly within the private sector. Hence, corporate entrepreneurship is most commonly seen as being within the private sector domain. This focus is partly attributed to the association between entrepreneurship and profitability, typically considered in the context of private sector organizations (e.g., Zahra 1993; Zahra, Covin 1995; Antoncic, Hisrich 2001). Further responsibility for the perceived risks associated with entrepreneurial activity are viewed as being more appropriately assumed by private sector interests, rather than being the prerogative of public organizations established with public funds (Luke et al. 2010). Yet, the concept of entrepreneurship in the public sector is not new, and interest in public sector entrepreneurship is developing. Governments can and increasingly do go beyond indirect involvement, and take a more direct approach, by undertaking entrepreneurial activities themselves (Osborne, Gaebler 1992). Entrepreneurial success within state owned enterprises has been noted in countries such as New Zealand (Hood 1995), contention over corporatization versus privatization continues to emerge. Accordingly, private and public sector organizations are tested in this study to reveal the commonalities and differences between the two sectors.

Private and public sector organizations have diverse roles in society and can be seen as different in terms of their 'mission' (Austin et al. 2006). Private organizations sell products or services to generate growth and profitability for shareholders. Public organizations are driven by multiple, intangible, social and political objectives rather than economic ones (Morris, Jones 1999). The demands placed on private and public sector organizations are quite different, suggesting that the approach to corporate entrepre- 


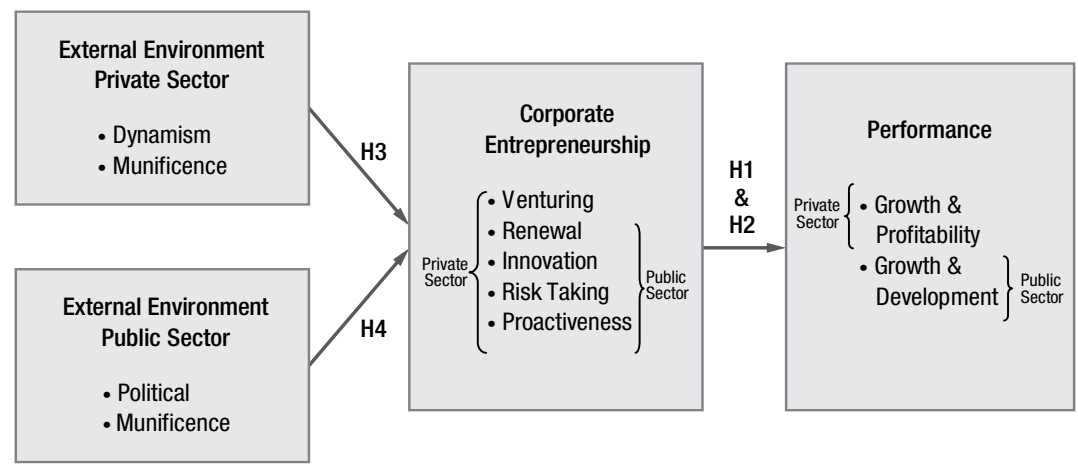

Fig. 1. Private and public sector corporate entrepreneurship model

neurship should be tailored to fit the needs of each sector. Therefore, research variables were chosen for the current study based on their appropriateness as components of a private and public sector corporate entrepreneurship model. This study discusses the literature that describes the key constructs and dimensions of corporate entrepreneurship, external environment and performance and links this to the private-public differences literature. The defined model (Fig. 1) posits that the organization's pursuit of corporate entrepreneurship is directly related to its performance as well as indirectly related to performance through key external environment dimensions. Given that corporate entrepreneurship may be a "generally effective means for improving long-term company financial performance" (Zahra, Covin 1995: 44), this is not hypothesized in the context of private and public sector, a more appropriate test is for the direct association between corporate entrepreneurship and organizational performance. This study begins by relating corporate entrepreneurship to performance and then specific external environment dimensions to corporate entrepreneurship and then to performance.

\section{Hypotheses development}

\subsection{Corporate entrepreneurship}

Corporate entrepreneurship is an integral part of the strategic management of the organization (Burgelman 1983; Barringer, Bluedorn 1999; Teng 2007), therefore, scholars and practitioners are interested in understanding its relationship with performance (Dess et al. 2003). Most researchers assert that corporate entrepreneurship is a multidimensional organizational level concept (Guth, Ginsberg 1990; Sharma, Chrisman 1999; Morris et al. 2008) they differ as to its individual dimensions. Researchers have advanced many different terms for corporate entrepreneurship, including internal corporate entrepreneurship, intrapreneurship, corporate venturing and organizational entrepreneurship (e.g., Sharma, Chrisman 1999; Antoncic, Hisrich 2001; Morris et al. 2008). Distinct dimensions of corporate entrepreneurship emerging from the literature include venturing, renewal, innovation, risk taking and proactivity as the ultimate strategy for achieving goals and objectives (e.g., Miller 1983; Guth, Ginsberg 1990; Antoncic, Hisrich 2001; Morris et al. 2008). 
Corporate entrepreneurship can include redefining the organization's existing products or services, developing new markets, or forming autonomous or semi-autonomous business units (Hisrich et al. 2010). Venturing is concerned with the organization's creation of new business by expanding operations in new or existing markets (Zahra 1996). Renewal is achieved through the redefinition of the firm's mission by redeploying resources, which leads to new combinations of products and technologies (Guth, Ginsberg 1990). Innovativeness reflects a tendency to support new ideas, novelty, experimentation, and creative processes, departing from established practices and technologies (Lumpkin, Dess 1996). Risk taking is to "the degree to which managers are willing to make large and risky resource commitments" (Miller, Friesen 1978: 923). Proactiveness refers to a posture of anticipating and acting on future wants and needs in the marketplace (Lumpkin, Dess 1996).

Some researchers have treated the relationship among these dimensions and the overall corporate entrepreneurship constructs as distinct dimensions with no discussion of their interrelationships (Zahra 1996). While, the dimensions of corporate entrepreneurship are within existing organizations, each may have its own antecedents and consequences (Sharma, Chrisman 1999). Alternatively, researchers have suggested a common core among venturing, renewal and innovation, and that they "are all important and legitimate parts of the concept of corporate entrepreneurship" (Morris et al. 2008: 12). Accordingly, this study views corporate entrepreneurship as a construct that gives rise to distinct, but at times complementary acts.

Corporate entrepreneurship in the public sector has been explored as a deliberate search for innovative change (Linden 1990; Kearney et al. 2010), the generation of new sources of revenue and the provision of enhanced services through the involvement of citizens (Bellone, Goerl 1992), and continuous innovation to enhance efficiency and effectiveness (Osborne, Gaebler 1992). The underlying drive for public sector entrepreneurship is to create value for citizens (Morris, Jones 1999; Currie et al. 2008). Corporate entrepreneurship in the private sector provides the potential means for revitalizing organizations (Zahra, Covin 1995) through risk taking, innovation and proactive competitive behaviors (Guth, Ginsberg 1990). This requires finding new ways of doing business, developing new technologies, products and services, and entering new markets in new organizational forms (Teng 2007). Corporate entrepreneurship in the private sector is driven by the opportunity to revitalize organizations and improve financial performance (e.g., Zahra, Covin 1995; Antoncic, Hisrich 2001) and create private value (Currie et al. 2008).

Corporate entrepreneurship is examined in terms of venturing, renewal, innovativeness, risk taking and proactiveness in the private sector and corporate entrepreneurship in terms of renewal, innovativeness, risk taking and proactiveness in the public sector. Narayanan et al. (2009) stated that corporate venturing focuses on the various steps and processes associated with creating new businesses and integrating them into the organization's overall business portfolio. Based on this premise and because corporate venturing involves entering new businesses through the creation or purchase of new business organizations (Chesbrough 2002), this construct was not applicable to the public sector 
state and semi-state enterprises in Ireland because public sector enterprises mostly do not create or purchase new business organizations.

Defining private and public sector corporate entrepreneurship requires appreciating the motivations of individuals who: take the risks associated with conceiving, have particular values and competencies, seek opportunities, and develop innovative responses. This forms the basis of the definition used in this study: corporate entrepreneurship in the private and public sector is an individual or group of individuals undertaking desired activity to initiate change within the organization, adapt, innovate and facilitate risk, with personal goals and objectives being less important than the generation of results for the organization.

\subsection{External environment - antecedent of corporate entrepreneurship}

Corporate entrepreneurship is influenced by several factors (for example, dynamism and munificence elements) in the external environment. As research on corporate entrepreneurial activity has evolved, numerous researchers (e.g., Miller 1983; Covin, Slevin 1991; Zahra, Covin 1995; Antoncic, Hisrich 2001) have acknowledged the importance of the external environment in promoting and supporting corporate entrepreneurship. Corporate entrepreneurship has the goal of generating greater alignment between the organization and conditions in its external environment (Hornsby et al. 2009).

External environment variables dynamism and munificence have been recognized in the literature as playing a profound role in influencing corporate entrepreneurship (e.g., Zahra 1991, 1993; Antoncic, Hisrich 2001; Simsek et al. 2007). Dynamism can provide more opportunities for the entrepreneurial organization to exploit, while hostile conditions provide a strong incentive for organizations to pursue innovation as a source of competitive advantage (Russell 1999). Dynamism (instability or turbulence) is the degree of environmental predictability; it is manifested in the variance in the rate of market and industry change and the level of uncertainty about forces that are beyond the control of individual businesses (Aldrich 1979; Dess, Beard 1984). According to Antoncic and Hisrich (2001: 503), "Dynamism refers to perceived instability and continuing changes in the firm's market." Corporate entrepreneurship is thought to be influenced by environmental changes in industry competitive structure and the underlying technologies. Highly dynamic environments have a greater chance of inducing high levels of activation among entrepreneurs than less dynamic environments (Baron, Tang 2011). Highly dynamic environments are unpredictable and changing and often involve high levels of risk and uncertainty that necessitate making key decisions based on incomplete information (Miller 2007). These conditions can result in high levels of stress and this in turn usually involves high levels of activation (e.g., Stranks 2005). The ability of a public sector organization to respond to their changing circumstances is significantly limited not only by resources but also by the management philosophies and structures that characterize public enterprises (Morris, Jones 1999). Based on this premise, dynamism was only examined in private sector organizations in this study.

Environmental munificence reflects the richness of opportunities for corporate entrepreneurship and renewal in an industry (Aldrich 1979). Keats and Hitt (1988) concluded 
that, generally, a munificent environment can present opportunities for expansion and can enable an organization to generate slack resources in support of growth. The more munificent the environment, the greater the expected internal rate of return on corporate entrepreneurship (Simsek et al. 2007). Essentially, this is because in munificent environments performance outcomes from proactive investments can be evaluated with a greater degree of accuracy. Conversely, the less munificent the environment, the more hostile it becomes. Private sector organizations need to adapt to increased environmental munificence in order to identify new opportunities that will strengthen their competitiveness. Public sector organizations also need to be able to adapt to the increased environmental munificence in order to find new opportunities that will strengthen their position and maximize the spending of public funds particularly during times of economic downturn. Munificence was examined in both the private and public sector organizations in this study.

Political environment is a fundamental dimension of the external environment, and has a significant impact on public sector organizations in terms of new laws, rules or regulations that could significantly affect performance. According to Nutt (2005: 5), "The external environment of a public organization is littered with political considerations." As a result of political constraints, there are frequent changes in policy and the imposition of short time-horizons on public managers. The views of opinion leaders, outright manipulation by legislators and interest groups, and opposition to a public sector organization's prerogatives are usually more important than the economic issues more critical for private organizations. Public sector organizations need to manage the diverse political environmental factors facing their organization (Kearney et al. 2010). It follows that because the pursuit of corporate entrepreneurship in the public sector involves public scrutiny there is a greater need to understand, assess and predict the political landscape that shapes the market environment where opportunities may arise. This is particularly evident when there is significant change and turbulence within a market. These changes make it necessary for public sector organizations to adapt quickly.

\subsection{Organizational performance - consequence of corporate entrepreneurship}

Private sector entrepreneurs are largely driven by profit (Schumpeter 1934) and their performance is usually measured by financial returns (Austin et al. 2006). The profit orientation in the private sector is not appropriate in the public sector because profitability is not their primary goal (Ramamurti 1986). Moreover, the public sector entrepreneur identifies market opportunities within the political landscape, maximizes the entrepreneurial potential to enhance performance, and carries stakeholders in a way that permits risk as well as recognize the stewardship of public sector resources (Currie et al. 2008). It follows that the pursuit of corporate entrepreneurship in the public sector is driven by a desire to change, adapt, innovate and entertain risk to generate a force at the institutional level (Forster et al. 1996) and usually has both social and economic goals (Thompson, Doherty 2006).

Engaging in corporate entrepreneurial activities are fundamental choices that organizations make, and have widespread and significant implications for performance and 
growth in numerous contexts (Zahra 1996). Hence, the performance variables examined in this research are growth and profitability for the private sector and growth and development for the public sector. Corporate entrepreneurship is essentially growth oriented (Lumpkin, Dess 1996). Growth and profitability are performance dimensions of corporate entrepreneurship in the private sector (Antoncic, Hisrich 2001; Antoncic, Scarlat 2005). Hence, in the private sector, engaging in corporate entrepreneurship may result in higher levels of growth, profitability, or newly created wealth than organizations that do not (e.g., Kanter 1984; Pinchot 1985; Morris et al. 2008).

In the public sector, entrepreneurial opportunities are explored differently as renewal, innovativeness, risk taking and proactiveness can be affected by the political agenda of the state. Public sector performance data is often missing and hard to collect and what constitutes good performance can be augmentable (Nutt 2005). This makes for a greater challenge for measuring performance within the public sector. Corporate entrepreneurship is integral to economic growth (e.g., Wenneker, Thurik 1999; Carree, Thurik 2003) and economic development (e.g., Schumpeter 1934; Kirzner 1997). Since economic well being and employment are concerns in the public sector, therefore, public sector organizations that operate entrepreneurially have the opportunity to promote economic growth and development (Minniti 2008; Kearney et al. 2010). Thus, public sector organizations that operate entrepreneurially encourage and support the opportunities for economic growth and development that leads to generating alternative revenues, improving internal processes, and developing innovative solutions to meet social and economic needs.

Table 1 highlights the similarities and differences between private and public sector corporate entrepreneurship and identifies constructs and dimensions tested in the following hypotheses (which are postulated on the basis of the above discussion):

H1: Corporate entrepreneurship will be positively related to the growth and profitability of a private sector organization.

H2: Corporate entrepreneurship will be positively related to the growth and development of a public sector organization.

H3: The external environment (increased dynamism and increased munificence) - performance relationship (growth and profitability) is mediated by corporate entrepreneurship. External environment has a positive impact on corporate entrepreneurship that in turn, has a positive impact on organizational performance in the private sector.

H4: The external environment (political adaptability and increased munificence) - performance relationship (growth and development) is mediated by corporate entrepreneurship. External environment has a positive impact on corporate entrepreneurship that in turn, has a positive impact on organizational performance in the public sector. 
Table 1. Similarities and differences between private sector and public sector corporate entrepreneurship (emerging from the literature)

\begin{tabular}{ccc}
\hline Constructs/ & Private Sector Corporate & Public Sector Corporate \\
Dimensions & Entrepreneurship & Entrepreneurship \\
\hline
\end{tabular}

Corporate Entrepreneurship

Venturing Venturing can result in new business Corporate venturing focuses on creatcreation within an existing organiza- ing new businesses and integrating them tion (Stopford, Baden-Fuller 1994), into the organization's overall business regardless of the level of autonomy portfolio (Narayanan et al. 2009). Given (Antoncic, Hisrich 2001). Venturing the nature of public sector enterprises can occur throughout the organiza- where profitability is not their primary tion and is more likely when an or- goal (Ramamurti 1986), they do not ganization is preoccupied with growth have the same drive and requirement to and aims to improve profitability and engage in corporate venturing activities. competitiveness (Zahra 1993), which is a key objective for many private sector organizations.

Renewal Renewal requires developing or Renewal activities enhance a firm's adopting new organizational struc- ability to compete and take risks (Miller tures that spur innovation and ventur- 1983). Public sector organizations that ing (S. A. Zahra, P. H. Zahra 1992), engage in renewal aim to create value it is a strategic aspect of corporate for citizens by bringing together unique entrepreneurship (Morris et al. 2008), combinations of public and/ or private flexibility and adaptability is funda- resources to exploit social opportunimental to achieve renewal in the pri- ties; learn to use external forces to initivate sector. ate and achieve internal change.

Innovation Innovation is a premier mechanism Public sector innovation tends to be for rejuvenating or redefining organi- more concerned with novel process zations (Kelley et al. 2009). Product improvements, new services, and new and service innovation is a fundamen- organizational forms (Morris, Jones tal aspect of private sector entrepre- 1999). Public sector innovation needs neurial organizations. to be encouraged and facilitated through new ideas and creativity (Kearney et al. 2009).

Risk Taking Risk factors are identified in the pri- Calculated risk taker; risk and reward vate sector and employees' aim to trade-offs favor avoiding mistakes; lowminimize them as much as possible; er financial incentives; does not share moderate risk taker; recognizes that enterprises profits (Morris, Jones 1999; risks are career related; higher finan- Ramamurti 1986), is part of the public cial incentives; profitability is funda- sector organizational culture. mental to generate income (Hornsby et al. 2002; Ramamurti 1986).

Proactivity Private sector employees have greater Public sector proactivity needs to be acflexibility to pursue opportunities in- tion orientated, with a commitment to dependent of the resources they cur- change (Kearney et al. 2009). rently control; doing new things and departing from the customary to pursue opportunities (Timmons 1994). 
Continue of Table 1

\begin{tabular}{ccc}
\hline Constructs/ & Private Sector Corporate & Public Sector Corporate \\
Dimensions & Entrepreneurship & Entrepreneurship \\
\hline
\end{tabular}

External Environment

\begin{tabular}{ll}
\hline Munificence & $\begin{array}{l}\text { Munificence enables organizations to Increased munificence will lead to fun- } \\
\text { access external resources for support damentally different approaches in man- } \\
\text { during periods of internal and exter- aging the public sector organization, } \\
\text { nal problems (Hambrick, Finkelstein therefore public sector organizations } \\
\text { 1987). The more munificent the en- need to be able to adapt to increased } \\
\text { vironment, the greater the expected munificence (Kearney et al. 2007). } \\
\text { internal rate of return on corporate } \\
\text { entrepreneurship (Simsek et al. 2007). }\end{array}$ \\
\hline $\begin{array}{l}\text { Dynamism can provide more op- Dynamism refers to the extent to which } \\
\text { portunities for the entrepreneurial environments in which new businesses } \\
\text { organization to exploit, while hostile operate are subject to unpredictable and } \\
\text { conditions provide a strong incentive rapid change and high levels of uncer- } \\
\text { for organizations to pursue innovation tainty (Dess, Beard 1984). While pub- } \\
\text { as a source of competitive advantage lic sector enterprises must manage the } \\
\text { (Russell 1999) in the private sector. } \\
\text { unpredictability and rapid change, they } \\
\text { are not engaging in the same degree of } \\
\text { competitiveness and drive for profit as } \\
\text { the private sector. }\end{array}$ \\
\hline
\end{tabular}

Political

As the degree of specialization in- Due to political constraints, there are creases in an organization, organi- frequent changes in policy and the zational members are more likely to imposition of short time-horizons on refer to professional accountability public managers. The political environmechanisms rather than bureaucratic ment facing the public sector includes, or political accountability mecha- inadequate funding or resources, legnisms (Romzek, Dubnick 1994). islative or regulatory constraints and There is less evidence of the politi- political opposition. An obstacle that cal impact of the environment on the is frequently emanating from both the private sector. While they must com- bureaucratic and the political arena is ply with policies, laws and regula- inadequate resources, which can result tions facing their organization, they from funding decisions made at either are more long-term oriented and not the bureaucratic or political levels (Bordealing with the same public scrutiny ins 2001).

as the public sector.

\begin{tabular}{|c|c|c|}
\hline \multicolumn{3}{|c|}{ Performance } \\
\hline $\begin{array}{l}\text { Growth and } \\
\text { Profitability }\end{array}$ & $\begin{array}{l}\text { Engaging in corporate entrepreneur- } \\
\text { ship in terms of entrepreneurial ori- } \\
\text { entations and behaviors may result in } \\
\text { higher levels of growth, profitability, } \\
\text { or new created wealth than organiza- } \\
\text { tions that do not (Kanter 1984; Pin- } \\
\text { chot 1985; Morris et al 2008). Identi- } \\
\text { fies risk factors and aims to minimize } \\
\text { them; higher financial incentives; } \\
\text { profitability is fundamental to gen- } \\
\text { erate income (Hornsby et al. 2002; } \\
\text { Ramamurti 1986). }\end{array}$ & $\begin{array}{l}\text { The public sector organization is not a } \\
\text { profit organization; the desirable per- } \\
\text { formance outcome is different due to } \\
\text { the non-quantifiability and perspective } \\
\text { differences. Risk and reward trade-offs } \\
\text { favor avoiding mistakes; lower financial } \\
\text { incentives; does not share enterprises } \\
\text { profits; lower financial incentives; do } \\
\text { not have a profit motive instead they are } \\
\text { guided by political and social objectives } \\
\text { (Morris, Jones 1999; Ramamurti 1986). }\end{array}$ \\
\hline
\end{tabular}


End of Table 1

\begin{tabular}{|c|c|c|}
\hline $\begin{array}{l}\text { Constructs/ } \\
\text { Dimensions }\end{array}$ & $\begin{array}{l}\text { Private Sector Corporate } \\
\text { Entrepreneurship }\end{array}$ & $\begin{array}{l}\text { Public Sector Corporate } \\
\text { Entrepreneurship }\end{array}$ \\
\hline $\begin{array}{l}\text { Growth and } \\
\text { Development }\end{array}$ & $\begin{array}{l}\text { Entrepreneurial activity can take the } \\
\text { form of imitative or research based } \\
\text { labor and the substantial presence of } \\
\text { either has a positive effect on growth } \\
\text { (Minniti, Levesque 2010). However, } \\
\text { private sector organizations can be } \\
\text { constrained by narrow profit; it can } \\
\text { be more difficult to access and obtain } \\
\text { funding for risky projects; difficult to } \\
\text { raise capital; can be restrictions on the } \\
\text { growth and power of the enterprise; } \\
\text { profit oriented (Ramamurti 1986). }\end{array}$ & $\begin{array}{l}\text { Exploits entrepreneurial opportunities } \\
\text { differently from the private sector; for } \\
\text { example renewal, innovation, proactiv- } \\
\text { ity and risk taking can be affected by } \\
\text { political agenda of the state. Public sec- } \\
\text { tor organizations that operate entrepre- } \\
\text { neurially provide a fundamental basis } \\
\text { for understanding the organization; as } \\
\text { well as supporting the opportunity to } \\
\text { promote economic growth and devel- } \\
\text { opment (Minniti 2008). }\end{array}$ \\
\hline
\end{tabular}

\section{Methodology}

\subsection{Sample and data collection}

To test this model, survey data was collected from a sample of private sector organizations in the United States and in Slovenia and public sector organizations in Ireland. In order to achieve good cross-national sample diversity, random samples of existing firms with 50 or more employees were selected from three diverse countries in terms of size and entrepreneurship development. The United States was selected because it is a large, developed and advanced economy that is a leader in entrepreneurship with a long tradition in the area. Slovenia was selected because it is a small transition economy from Central and Eastern Europe with a short entrepreneurship tradition. Ireland is a representative country in the EU, and an economy undergoing major transition in Europe with limited previous public sector corporate entrepreneurship research.

The core focus of this study is corporate entrepreneurship therefore organizations with 50 or more employees were selected. The industries included in the private sector samples were: manufacturing consumer and industrial goods, construction, retail and wholesale trade, engineering, research and development, consumer and business services, transportation, and public utilities. A total of 500 organizations meeting these criteria for the United States sample were randomly selected from a list of the United States private organizations obtained from the Dun and Bradstreet database of companies. Meeting the criteria, another 500 organizations for the Slovenian sample were randomly selected from the PASEF (Podatkovno analiticno sredisce Ekonomske fakultete) a database of Slovenian incorporated companies (cross-checked with data from the Slovenian Chamber of Commerce). Public sector state and semi-state enterprises included all government departments and commercial businesses that are beneficially owned either fully or partially by the Irish Government. The criteria for inclusion was that the organizations be civil service (e.g., Department of Finance, Defense, Justice, Welfare, Revenue Commissioners, Office of the Attorney General, Data Protection Agency), local government and administration (e.g., all County Enterprise Boards) health service (HSE), state 
sponsored bodies (e.g., Aer Lingus, Bord Bia, Bord Gais, ESB, Enterprise Ireland, IDA Ireland), or higher education institutions including universities and institutes of technology in Ireland - which provided interesting research for testing our model because of the diversity of the Irish public sector. A total of 246 public sector state and semi-state enterprises meeting these criteria were selected for the Irish sample. This list was obtained from the Irish Public Administration 41 ${ }^{\text {st }}$ Edition Administration Yearbook and Diary 2007 (cross-checked with telephone calls to each organization).

As the organization was the unit of analysis, the chief executive or most senior manager was requested to complete the questionnaire as they are the ones most likely to be well informed about "strategic issues that explicitly entail organization-wide or external focus" (Sharfman et al. 1988: 6) such as the organization's external and internal environment and corporate entrepreneurship. Since reliance on single informants can potentially introduce the same source bias, steps were taken to mitigate this bias. Following recommendations in Huber and Power (1985), all survey items were carefully constructed and where possible used valid pretested multidimensional constructs. Given that the constructs used were of a higher order nature assessed by established multipleitem measures, this reduces the likelihood of respondents artificially inflating relationships among them was reduced (Harrison et al. 1996). Surveying the senior manager as the key informants for each enterprise also reduces the potential of bias. The questionnaire was developed in three stages. First, an initial version was developed from existing questionnaires used in previous private and public sector research (measures are described in the Variables and measurement section). This was then reviewed by seven academic scholars. Second, based on their feedback, the questionnaire was refined and pre-tested among individuals that were not part of the final research study. Third, based on the results from the pretest, a final questionnaire was constructed.

In the United States, 56 responses were received (11 percent response rate), in Slovenia 145 responses were received (29 percent response rate) and in Ireland 134 responses were received (55 percent response rate) "consistent with the 10-12 percent rate typical for mailed surveys to top executives" (Hambrick et al. 1993: 407). Two blank questionnaires in Ireland, one in Slovenia and four in the United States were returned by organizations unwilling to participate in the study. Additionally, four questionnaires were excluded with incomplete data. Thus, 51 organizations from the United States, 141 organizations from Slovenia and 134 organizations in Ireland gave responses that were usable for analysis. Even though the United States response rate was relatively low, the distribution of the sample was quite similar to the population. The United States sample had a median age of 21-50 years, and median size of 100-249 employees. The proportion of large organizations with more than 1000 employees was 18 percent, and the median size in terms of total sales was $\$ 10-50$ million. The industries in the sample were: manufacturing of industrial goods 37 percent, manufacturing of consumer goods 18 percent, consumer and business services 10 percent, trade 12 percent, and construction 6 percent. The Slovenian sample had a median age of 11-20 years and median size of 50-99 employees. The proportion of large organizations with over 1000 employees was 8 percent, and the median size in terms of total sales was \$5-10 million. Industries 
represented included: manufacturing of industrial and consumer goods 51 percent, consumer and business services 11 percent, trade 7 percent, and construction 6 percent. In addition, the answers to corporate entrepreneurship and performance items were well distributed across the answer range. The Irish sample had a median age of 30 years, and median size of 185 employees. The proportion of large organizations with more than 1000 employees was 6.7 percent. The sectors in the sample were: civil service 19 percent, local government 19 percent, state sponsored body 52 percent, university 2 percent, and institute of technology 8 percent.

Analysis of variance (ANOVA) was conducted to ascertain the appropriateness of combining public sector state and semi-state enterprises. The ANOVA tests indicated that the state and semi-state enterprises exhibit no overall differences in terms of their individual external environment, internal environment, corporate entrepreneurship and performance scores. Using the extrapolation technique non-response bias was assessed on the basis that later respondents could be more like non-respondents (Armstrong, Overton 1977). The responses of later respondents were found not to be statistically different (sig. 0.05) from responses of earlier respondents for all questionnaire items for all samples. This indicates that non-response bias was not present. These groups were then compared in terms of the mean responses on each variable, using a t-test. No significant differences were found between the groups, therefore, concluding that non-response bias was an unlikely threat.

\subsection{Variables and measurement}

Mediating variables - corporate entrepreneurship. Consistent with earlier discussions on corporate entrepreneurship, the pursuit of corporate entrepreneurship was measured using previously established items and scales. In the private sector organizations the construct represented by 37 items rated on a five-point scale. Based on Zahra (1993), Knight (1997), and Antoncic and Hisrich (2001) respondents were asked to assess their organizational level of venturing on 15 items (e.g., financial feasibility of new ventures); renewal on 13 items (e.g., redefining the industries in which it competes). Nine item measures were used for innovativeness (e.g., number of new products or services), risk taking (tendency towards risk projects), and proactiveness (new techniques for new products/ services, administration, operating technologies....). With the exception of venturing, the same measures were used for the public sector aspect of the study. The construct was represented by 22 items rated on five-point scale measuring renewal, innovativeness, risk taking and proactiveness.

Independent variables - external environment. Based on Morris (2006), the political environment construct was measured using a refined version of the eleven-item, five-point Likert scale ( 1 - Minimal Threat to 5 - Significant Threat). Respondents were asked to assess their organization's level of political threat (e.g., regulatory requirements). From Zahra (1993) and Antoncic and Hisrich (2001), the construct of dynamism (six items, e.g., technological changes) using a five-point Likert scale (1 - Minor Change to 5 - Major Change), and munificence (nine items, e.g., opportunities for growth in the sector are abundant) using a five-point Likert scale ( 1 - Very Untrue to 5 - Very True). 
Dependent variables - organizational performance. Variables of performance, the dependent variables in the model, were measured in terms of growth and profitability in absolute as well as relative terms in the private sector organizations (Antoncic, Hisrich 2001). Absolute growth was measured by two items. While the first asked the average annual growth in the number of employees in the last three years, the second asked the average annual growth in sales in the last three years. Relative growth was assessed by growth in market share (Chandler, Hanks 1993) in the last three years. Absolute profitability was assessed by three items: average annual return on sales, average return on assets, and average annual return on equity in the last three years. Relative profitability was measured by two subjective measures of firm performance relative to competitors (Chandler, Hanks 1993). Respondents were asked to rate their organization's profitability in comparison to all competitors as well as to competitors that were at approximately the same age and stage of development (Antoncic, Hisrich 2001).

Performance was measured in terms of growth and development in the public sector. The construct of absolute growth was measured using two items proposed by Antoncic and Hisrich (2001). The first item asked for the average annual growth in the number of employees in the last three years; the second asked for the average annual growth in budget in the last three years. Relative growth was assessed by growth in market share in the last three years (Antoncic, Hisrich 2001). Respondents were asked to give their best estimate (or a range) in percentage terms in response to the questions in this section to focus specifically on this research area, which is public sector corporate entrepreneurship. The construct of development was measured using items proposed by Antoncic and Hisrich (2001) measuring the percentage of the organization's revenue generated from products that did not exist three years ago. Additionally, respondents were asked if there were changes (in percentage terms) in the number of clients/customers served over the last three years. Respondents were asked to give their best estimate (or a range) in percentage terms in response to the questions in this section. Modifications were made to the original format and wording to focus specifically on public sector corporate entrepreneurship. While it is recognized that managerial assessment of organizational performance may produce unstable estimates, evidence suggests that such executive reports of performance tend to be significantly correlated with objective measures of performance (e.g., Robinson, Pearce 1988).

Control variables. Consistent with previous theory four control variables were used in this private and public sector study - organizational age (number of years the organization exists), organizational size (full-time employees), organizational sector (category in which the organization is in) and organizational strategy (organization's grand strategy in the past three years in terms of stability, internal growth, external acquisitive growth, and retrenchment strategy). Organizational age and size were used because older and larger organizations often tend to be more technocratic in their decision making and more mechanistic in their structures (Fredrickson 1986; Powell 1992). Organizational sector was used due to the interindustry differences in entrepreneurial activities, opportunities for innovation (Covin, Slevin 1991; Zahra 1993). Sector was used as a control 
variable as there is diversity among both private and public organizations. In order to assure direct comparability between countries, the organizational sector question (category in which the organization is in) was different than country official sector classifications. Organizational strategy was included as a control variable as organizational strategy, particularly growth strategies as opposed to stability strategies (Hitt et al. 1982), can influence corporate entrepreneurship and performance (Zahra 1991).

\section{Results}

The hypotheses were tested using hierarchical regression analysis. Control variables were entered as independent variables in the regression equation. The construct reliability was assessed using coefficient alpha. All scales demonstrated good reliability, with the exception of one construct - environmental dynamism in the private sector, which had modest reliability. Two-tailed tests were used with the possibility of collinearity among the variables tested in the regression analysis; there was no collinearity found among the variables. Nonetheless, variance inflation factors (VIF) were examined. All the VIF's are within the appropriate scale of $<10$. Tables 2, 3 and 4 show the summary statistics (i.e., mean score, standard deviations and Cronbach alpha coefficients) and the correlation matrix for each of the measures.

Table 2. Summary descriptive statistics, reliabilities and correlation matrix (private sector, the United States)

\begin{tabular}{|c|c|c|c|c|c|c|c|c|c|c|c|c|}
\hline $\begin{array}{l}\text { Vari- } \\
\text { ables }\end{array}$ & $\mathrm{N}$ & Mean & $\begin{array}{c}\text { Std } \\
\text { Deviat }\end{array}$ & $\begin{array}{l}\text { Cronb } \\
\text { Alpha }\end{array}$ & 1 & 2 & 3 & 4 & 5 & 6 & 7 & 8 \\
\hline $\begin{array}{l}\text { Age of } \\
\text { Organ }\end{array}$ & 51 & $\begin{array}{l}5.04 \\
(1-6)\end{array}$ & 1.00 & & & & & & & & & \\
\hline $\begin{array}{l}\text { Size of } \\
\text { Organ }\end{array}$ & 51 & $\begin{array}{c}3.51 \\
(1-6)\end{array}$ & 1.46 & & .192 & & & & & & & \\
\hline Sector & 51 & $\begin{array}{c}1.71 \\
(1-3)\end{array}$ & .76 & & .121 & .030 & & & & & & \\
\hline Strategy & 50 & $\begin{array}{l}2.56 \\
(1-3)\end{array}$ & .58 & & -.060 & .274 & $-.288 *$ & & & & & \\
\hline $\begin{array}{l}\text { Dyna- } \\
\text { mism }\end{array}$ & 50 & 2.78 & .66 & $\begin{array}{c}.531 \\
(6 \text { items) }\end{array}$ & -.075 & .001 & .231 & -.279 & & & & \\
\hline $\begin{array}{l}\text { Munifi- } \\
\text { cence }\end{array}$ & 51 & 3.56 & .73 & $\begin{array}{c}.867 \\
\text { (9 items) }\end{array}$ & -.025 & .111 & -.150 & .219 & $.307 *$ & & & \\
\hline $\begin{array}{l}\text { Corp. } \\
\text { Ent. }\end{array}$ & 51 & 3.31 & .52 & $\begin{array}{c}.894 \\
\text { (37items) }\end{array}$ & -.024 & .059 & -.262 & $.362 * *$ & .195 & $.449^{* *}$ & & \\
\hline $\begin{array}{l}\text { Perfor- } \\
\text { mance }\end{array}$ & 50 & 3.27 & .87 & $\begin{array}{c}.724 \\
\text { (5 items) }\end{array}$ & -.262 & .001 & $-.314^{*}$ & .273 & .139 & .127 & .201 & 1 \\
\hline
\end{tabular}

Notes: ** Correlation is significant at the 0.01 level (2-tailed); ${ }^{*}$ Correlation is significant at the 0.05 level (2-tailed). 
Table 3. Summary descriptive statistics, reliabilities and correlation matrix (private sector, Slovenia)

\begin{tabular}{|c|c|c|c|c|c|c|c|c|c|c|c|c|}
\hline $\begin{array}{l}\text { Vari- } \\
\text { ables }\end{array}$ & $\mathrm{N}$ & Mean & $\begin{array}{c}\text { Std } \\
\text { Deviat }\end{array}$ & $\begin{array}{l}\text { Cronb } \\
\text { Alpha }\end{array}$ & 1 & 2 & 3 & 4 & 5 & 6 & 7 & 8 \\
\hline $\begin{array}{l}\text { Age of } \\
\text { Organ }\end{array}$ & 140 & $\begin{array}{c}4.87 \\
(1-6)\end{array}$ & 1.16 & & & & & & & & & \\
\hline $\begin{array}{l}\text { Size of } \\
\text { Organ }\end{array}$ & 141 & $\begin{array}{c}3.32 \\
(1-6)\end{array}$ & 1.23 & & $.254 * *$ & & & & & & & \\
\hline Sector & 141 & $\begin{array}{c}1.67 \\
(1-3)\end{array}$ & .74 & & .092 & $-.198^{*}$ & & & & & & \\
\hline Strategy & 135 & $\begin{array}{l}2.27 \\
(1-3)\end{array}$ & .67 & & .011 & .021 & $-.176^{*}$ & & & & & \\
\hline $\begin{array}{l}\text { Dyna- } \\
\text { mism }\end{array}$ & 141 & 2.89 & .71 & $\begin{array}{c}.490 \\
(6 \text { items) }\end{array}$ & .153 & .096 & .064 & .033 & & & & \\
\hline $\begin{array}{l}\text { Munifi- } \\
\text { cence }\end{array}$ & 141 & 3.23 & .65 & $\begin{array}{c}.817 \\
\text { (9 items) }\end{array}$ & .038 & .104 & -.078 & .110 & $.389 * *$ & & & \\
\hline $\begin{array}{l}\text { Corp. } \\
\text { Ent. }\end{array}$ & 141 & 3.03 & .66 & $\begin{array}{c}.949 \\
\text { (37items) }\end{array}$ & .082 & $.192 *$ & -.144 & $.365 * *$ & $.334 * *$ & $.383 * *$ & & \\
\hline $\begin{array}{l}\text { Perfor- } \\
\text { mance }\end{array}$ & 141 & 2.19 & .86 & $\begin{array}{c}.831 \\
(5 \text { items })\end{array}$ & $-.257^{* *}$ & -.039 & -.029 & $.313 * *$ & .026 & .123 & $.405 * *$ & 1 \\
\hline
\end{tabular}

Notes: ** Correlation is significant at the 0.01 level (2-tailed); ${ }^{*}$ Correlation is significant at the 0.05 level (2-tailed).

Table 4. Summary descriptive statistics, reliabilities and correlation matrix (public sector, Ireland)

\begin{tabular}{|c|c|c|c|c|c|c|c|c|c|c|c|c|}
\hline $\begin{array}{l}\text { Vari- } \\
\text { ables }\end{array}$ & $\mathrm{N}$ & Mean & $\begin{array}{c}\text { Std } \\
\text { Deviat }\end{array}$ & $\begin{array}{l}\text { Cronb } \\
\text { Alpha }\end{array}$ & 1 & 2 & 3 & 4 & 5 & 6 & 7 & 8 \\
\hline $\begin{array}{l}\text { Age of } \\
\text { Organ }\end{array}$ & 129 & 66.37 & 121.88 & & & & & & & & & \\
\hline $\begin{array}{l}\text { Size of } \\
\text { Organ }\end{array}$ & 131 & 863.03 & 2476.8 & & .166 & & & & & & & \\
\hline Sector & 134 & 3.25 & 1.5 & & $-.237 * *$ & -.154 & & & & & & \\
\hline Strategy & 124 & 1.64 & .95 & & -.151 & .004 & $.265^{* *}$ & & & & & \\
\hline $\begin{array}{l}\text { Dyna- } \\
\text { mism }\end{array}$ & 115 & 2.33 & .62 & .758 & $.235^{*}$ & .126 & $.245^{* *}$ & .107 & & & & \\
\hline $\begin{array}{l}\text { Munifi- } \\
\text { cence }\end{array}$ & 128 & 3.39 & .60 & .777 & -.015 & -.035 & $.325^{* *}$ & .174 & $.487^{* *}$ & & & \\
\hline $\begin{array}{l}\text { Corp. } \\
\text { Ent. }\end{array}$ & 115 & 3.09 & .75 & .883 & -.097 & .165 & .012 & $.218^{*}$ & .101 & $.247 * *$ & & \\
\hline $\begin{array}{l}\text { Perfor- } \\
\text { mance }\end{array}$ & 114 & .637 & .40 & $\begin{array}{c}.698 \\
(5 \text { items })\end{array}$ & -.124 & .118 & .023 & .026 & $.232 *$ & $.315^{* *}$ & $.228 *$ & 1 \\
\hline
\end{tabular}

Notes: ** Correlation is significant at the 0.01 level (2-tailed); ${ }^{*}$ Correlation is significant at the 0.05 level (2-tailed). 
Common method bias is unlikely to result in significant interaction effects or distort such effects, for "artifactual interactions cannot be created; true interactions can be attenuated" (Evans 1985: 30). While it is recognized that correlations and coefficients may be spuriously high as a result of method specificity, "there is not a priori reason to suggest that the numerical difference between correlations of two variables measured in the same way at two levels of a third variable is influenced by method specificity" (Cummins 1972: 657). Studies have shown common method bias to have small effects at best (e.g., Lindell and Whitney 2001; Spector 2006), so the results are not likely to be adversely affected. In addition, all variables were pilot tested and modified for this research study, and steps were taken to ensure that findings are robust.

For the purpose of parsimony and measurement error reduction, composite measures were used where possible to test the model. There is little consensus in the literature regarding the appropriate sample size as researchers have proposed a minimum of five subjects per variable and no less than 100 individuals per analysis (Gorsuch 1983; Kline 2000; Coakes, Steed 2001). Subsequently innovation, proactivity and risk taking did not warrant inclusion in the current public sector study due to its response rate of 62, well below the cutoff point. The United States private sector study had a response rate of 51, also below the cutoff point, however, because the U.S. sample was used for validation, the issue of sample size is of much less importance than in the Slovenian sample, which was used for the analysis. Most current studies were conducted in the context of the United States or developed countries (e.g. Covin, Slevin 1989, 1989; Covin 1991; Zahra 1991, 1993; Zahra, Covin 1995); therefore, the results based on the Slovenian sample provide strong evidence of cross-cultural comparability of the corporate entrepreneurship model.

Hypothesis 1 suggests that corporate entrepreneurship (venturing, renewal, innovativeness, risk taking and proactiveness) is positively related to organizational performance in terms of growth and profitability in private sector organizations. In Table 5, the beta coefficient for the association between corporate entrepreneurship and performance is significant for Slovenian organizations (standardized coefficient .375, $\mathrm{p}<.001$ ). Therefore, the relationship among the dependent variable performance with independent variable corporate entrepreneurship is statistically significant $(r=.000)$. Hypothesis 1 is supported in the Slovenian data, but is not supported in the United States data.

Hypothesis 2 suggests that corporate entrepreneurship (renewal) is positively related to organizational performance in terms of growth and development in public sector organizations. In Table 6 , the beta coefficient for the association between corporate entrepreneurship (renewal) and performance is significant (standardized coefficient .258, $\mathrm{p}<.05$ ). Therefore, the relationship among the dependent variable performance with independent variable renewal is marginally supported in the public sector data.

To test Hypothesis 3 and Hypothesis 4, the three regression equations were used as recommended by Baron and Kenny (1986). Baron and Kenny indicated that the following conditions were necessary: the independent variable must affect the mediator in the first equation; the independent variable must be shown to affect the dependent variable 
Table 5. Regression analysis results (private sector)

\begin{tabular}{|c|c|c|}
\hline $\begin{array}{l}\text { Dependent Variable: } \\
\text { Performance }\end{array}$ & $\begin{array}{l}\text { Model } 1 \text { Hypothesis } 1 \\
\text { (the United States) }\end{array}$ & $\begin{array}{c}\text { Model } 1 \text { Hypothesis } 1 \\
\text { (Slovenia) }\end{array}$ \\
\hline \multicolumn{3}{|l|}{ Control Variables } \\
\hline Age of Organization (Years) & -.223 & $-.291 * * *$ \\
\hline Size of Organization (F/T Employees) & .000 & -.025 \\
\hline Sector & -.218 & .081 \\
\hline Strategy & .169 & $.194^{*}$ \\
\hline \multicolumn{3}{|l|}{ Independent Variables } \\
\hline \multicolumn{3}{|l|}{ Corporate Entrepreneurship: } \\
\hline $\begin{array}{l}\text { Venturing, Renewal, Innovation, Risk } \\
\text { Taking, Proactiveness }\end{array}$ & .078 & $.375 * * *$ \\
\hline Model R Square & .189 & .286 \\
\hline Adjusted R Square & .094 & .259 \\
\hline Model F & 1.999 & 10.345 \\
\hline P - Value (Sig.) & .098 & .000 \\
\hline $\mathrm{N}$ & 50 & 135 \\
\hline
\end{tabular}

Notes: Standardized regression coefficients are reported. ${ }^{*} \mathrm{p}<.05, * * \mathrm{p}<.01,{ }^{* * *} \mathrm{p}<.001$.

Table 6. Regression analysis results (public sector)

\begin{tabular}{lc}
\multicolumn{1}{c}{$\begin{array}{c}\text { Dependent Variable: } \\
\text { Performance }\end{array}$} & Model 1 Hypothesis 2 (Ireland) \\
\hline Age of Organization (Years) & -.186 \\
\hline Size of Organization (F/T Employees) & .004 \\
\hline Sector & .060 \\
\hline Strategy $\quad-.075$ \\
\hline Independent Variables & \\
\hline Corporate Entrepreneurship & $.258^{*}$ \\
\hline Renewal & .112 \\
\hline Model R Square & .062 \\
\hline Adjusted R Square & 2.246 \\
\hline Model F & .057 \\
\hline P - Value (Sig.) & 94 \\
\hline $\mathrm{N}$
\end{tabular}

Notes: Standardized regression coefficients are reported ${ }^{*} \mathrm{p}<.05,{ }^{*} \mathrm{p}<.01, * * * \mathrm{p}<.001$. 
in the second equation; and the mediator must affect the dependent variable in the third equation. If these conditions occur in the predicted direction, then the effect of the independent variable on the dependent variable must be less in the third equation than in the second equation. Perfect mediation holds if the independent variable has no effect when the mediator is controlled (Baron, Kenny 1986). The changes in R-squared of each model and the standardized regression coefficients are presented in Tables 7, 8 and 9.

In Hypothesis 3 for the private sector, Tables 7 and 8, Model 2, there is a positive relationship between munificence and corporate entrepreneurship (venturing, renewal, innovativeness, risk taking and proactiveness). The beta coefficient for the associations between environmental dynamism and munificence and corporate entrepreneurship is positive in the United States and Slovenia and statistically significant in Slovenia.

Table 7. Hierarchical regression analysis results - hypothesis four (private sector, the United States - mediation test)

\begin{tabular}{|c|c|c|c|c|}
\hline & 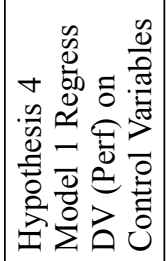 & 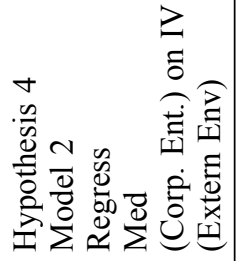 & 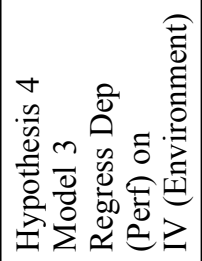 & 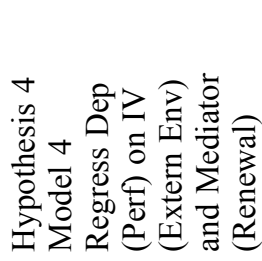 \\
\hline \multicolumn{5}{|l|}{ Control Variables } \\
\hline $\begin{array}{l}\text { Age of Organization } \\
\text { (Years) }\end{array}$ & -.222 & .058 & -.185 & -.185 \\
\hline $\begin{array}{l}\text { Size of Organization } \\
\text { (F/T Employees) }\end{array}$ & -.003 & -.072 & -.025 & -.026 \\
\hline Sector & -.231 & -.186 & -.287 & -.288 \\
\hline Strategy & .194 & $.342 *$ & .283 & .286 \\
\hline \multicolumn{5}{|l|}{ Independent Variables } \\
\hline \multicolumn{5}{|l|}{ External Environment: } \\
\hline Dynamism & & .252 & .292 & .294 \\
\hline Munificence & & .278 & -.069 & -.067 \\
\hline \multicolumn{5}{|l|}{ Mediation Variables } \\
\hline Corporate Entrepreneurship & & & & .008 \\
\hline Model R Square & .184 & .341 & .248 & .248 \\
\hline Adjusted R Square & .109 & .247 & .140 & .119 \\
\hline Model F & 2.472 & 2.624 & 2.303 & 1.927 \\
\hline P - Value (Sig.) & .058 & .005 & .052 & .090 \\
\hline $\mathrm{N}$ & 50 & 50 & 50 & 50 \\
\hline
\end{tabular}

Notes: Standardized regression coefficients are reported $* \mathrm{p}<.05, * * \mathrm{p}<.01, * * * \mathrm{p}<.001$. 
Table 8. Hierarchical regression analysis results - hypothesis four (private sector, Slovenia - mediation test)

\begin{tabular}{|c|c|c|c|c|}
\hline & 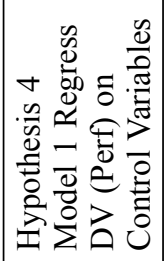 & 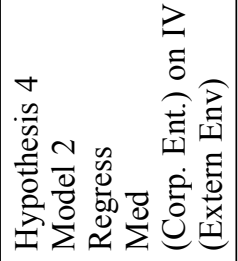 & 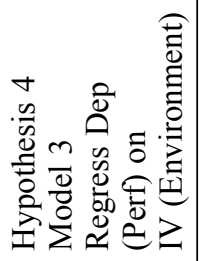 & 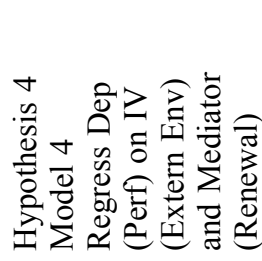 \\
\hline \multicolumn{5}{|l|}{ Control Variables } \\
\hline $\begin{array}{l}\text { Age of Organization } \\
\text { (Years) }\end{array}$ & $-.275 * *$ & .010 & $-.279 * *$ & $-.283 * * *$ \\
\hline $\begin{array}{l}\text { Size of Organization } \\
\text { (F/T Employees) }\end{array}$ & .036 & .124 & .026 & -.024 \\
\hline Sector & .061 & -.059 & -.064 & -.088 \\
\hline Strategy & $.326^{* * *}$ & $.317^{* * *}$ & $.316^{* * *}$ & $.188^{*}$ \\
\hline \multicolumn{5}{|l|}{ Independent Variables } \\
\hline \multicolumn{5}{|l|}{ External Environment: } \\
\hline Dynamism & & $.219 * *$ & .014 & -.074 \\
\hline Munificence & & $.245 * *$ & .096 & -.003 \\
\hline \multicolumn{5}{|l|}{ Mediation Variables } \\
\hline Corporate Entrepreneurship & & & & $.403 * * *$ \\
\hline Model R Square & .170 & .316 & .180 & .291 \\
\hline Adjusted R Square & .144 & .284 & .141 & .252 \\
\hline Model F & 6.639 & 9.853 & 4.677 & 7.446 \\
\hline P - Value (Sig.) & .000 & .000 & .000 & .000 \\
\hline $\mathrm{N}$ & 135 & 135 & 135 & 135 \\
\hline
\end{tabular}

Notes: Standardized regression coefficients are reported ${ }^{*} \mathrm{p}<.05,{ }^{* *} \mathrm{p}<.01,{ }^{* * *} \mathrm{p}<.001$.

With respect to the second condition (as indicated in Tables 7 and 8, Model 3), the relationship between the dependent variable performance with independent external environmental variable dynamism is positive in the United States and close to zero in Slovenia and the relationship between the dependent variable performance with independent external environmental variable munificence is close to zero in both the United States and Slovenia. As illustrated in Tables 7 and 8, Model 4, the environmental dynamism-performance relationship and the environmental munificence-performance relationship are mediated by corporate entrepreneurship in Slovenia, since they lost significance in the presence of corporate entrepreneurship. There is indication also that munificence may be mediated in the United States sample as it lost its coefficient size in the presence of corporate entrepreneurship. Overall, the relationship between the 
Table 9. Hierarchical regression analysis results - hypothesis four (public sector, Ireland - mediation test)

\begin{tabular}{|c|c|c|c|c|}
\hline & 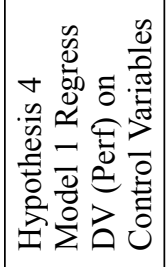 & 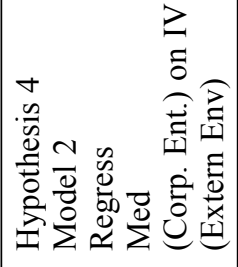 & 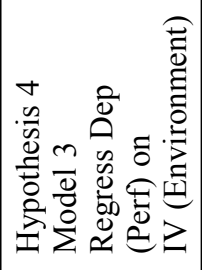 & 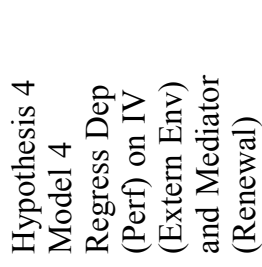 \\
\hline \multicolumn{5}{|l|}{ Control Variables } \\
\hline $\begin{array}{l}\text { Age of Organization } \\
\text { (Years) }\end{array}$ & -.176 & -.125 & $-.257^{*}$ & $-.218^{*}$ \\
\hline $\begin{array}{l}\text { Size of Organization } \\
\text { (F/T Employees) }\end{array}$ & .150 & .166 & .084 & .007 \\
\hline Sector & -.010 & -.132 & -.094 & -.057 \\
\hline Strategy & -.025 & .111 & -.123 & -.152 \\
\hline \multicolumn{5}{|l|}{ Independent Variables } \\
\hline \multicolumn{5}{|l|}{ External Environment: } \\
\hline Dynamism & & -.014 & .204 & .173 \\
\hline Munificence & & $.272 *$ & $.272 *$ & .244 \\
\hline \multicolumn{5}{|l|}{ Mediation Variables } \\
\hline Corporate Entrepreneurship & & & & $.247^{*}$ \\
\hline Model R Square & .042 & .116 & .156 & .234 \\
\hline Adjusted R Square & .005 & .052 & .095 & .162 \\
\hline Model F & 1.141 & 1.799 & 2.563 & 3.236 \\
\hline P - Value (Sig.) & .342 & .109 & .025 & .005 \\
\hline $\mathrm{N}$ & 107 & 88 & 89 & 81 \\
\hline
\end{tabular}

Notes: Standardized regression coefficients are reported $* \mathrm{p}<.05, * * \mathrm{p}<.01, * * * \mathrm{p}<.001$.

dependent variable performance with the two independent variables (dynamism and munificence) and mediator corporate entrepreneurship is partly present in private sector organizations. Thus, Hypothesis 3 was partially supported - corporate entrepreneurship mediates the relationship between munificence - performance and partially mediates the dynamism - performance relationship.

Hypothesis 4 was also partially supported for the public sector, Table 9, Model 2 illustrates that there is a positive relationship between munificence and corporate entrepreneurship (renewal). The beta coefficient for the association between munificence and corporate entrepreneurship (renewal) is statistically significant (standardized coefficient $.272, \mathrm{p}<.05$ ). Political environment (standardized coefficient -.014 ) is not related to corporate entrepreneurship (renewal). With respect to the second condition (as indicated 
in Table 9, Model 3), the relationship among the dependent variable performance with independent external environmental variable munificence is significant (standardized coefficient $.272, \mathrm{p}<.05$ ). However, the relationship between performance and political environment is not significant (standardized coefficient .204). As illustrated in Table 9, Model 4, political environment is not mediated by corporate entrepreneurship (renewal). However, munificence is mediated as it lost its significance in the presence of corporate entrepreneurship (renewal). Overall, the relationship among the dependent variable performance with the two independent variables (political and munificence) and mediator corporate entrepreneurship (renewal) is statistically significant. Hypothesis 4 was partially mediated, that is, corporate entrepreneurship (renewal) mediates the relationship between munificence - performance, but not the political environment - performance relationship.

\section{Discussions and conclusions}

The core of the developed and tested integrative model can be recapitulated as follows: (1) the pursuit of corporate entrepreneurship can enhance performance in the public as well as the private sector; (2) through the influence of corporate entrepreneurship, dynamism may have important effects on performance in the private sector while munificence may have important effects on performance in both the private and public sector. The tested model combines this reasoning and is based on a large body of research in several widely received theoretical perspectives including dynamic, munificent and political environment, corporate entrepreneurship, and performance in private and public sector organizations. Taken together, the theory and results of this study, advance theory and inform practice while also suggesting promising directions for future research.

\subsection{Implications for theory}

This study contributes to theory and literature on corporate entrepreneurship by developing and testing a meditational model that provides an explanation of key dimensions of the external environment - performance relationship in the private and public sector. The meditational model for the private sector and the meditational model for the public sector were presented together as the integrative model (see Figure 1). To date several studies have established the link between corporate entrepreneurship and performance (e.g., Zahra, Covin 1995; Dess et al. 2003), few have examined the mediating effect of corporate entrepreneurship on the external environment - performance relationship in the private sector (Antoncic, Hisrich 2001), and none has examined this relationship in the public sector. We developed and tested a meditational model that suggests that corporate entrepreneurship increases organizational performance in private sector organizations in Slovenia. It also suggests that corporate entrepreneurship in terms of renewal is the key dimension that improves performance in public sector organizations in Ireland. Corporate entrepreneurship mediated the relationship between dynamism and performance in Slovenia and munificence and performance in the United States, Slovenia and Ireland. Thus, we contribute to the corporate entrepreneurship literature by demonstrating dynamism (private sector) and munificence (private and public sector) as 
a mechanism for more deeply explaining, understanding and maximizing the association between corporate entrepreneurship and performance. As previously discussed the external environment has a strong influence on the existence of corporate entrepreneurial activity, the organization's pursuit of corporate entrepreneurship is yet to be linked to the external dimensions that impact and maximize corporate entrepreneurship activity, and in turn further enhance performance. We move this stream of research along by exploring the roles of corporate entrepreneurship in carrying the impact of external environment on performance in the private and public sector.

A second contribution is the important insight that dynamism (Slovenia) and munificence (Slovenia, United States and Ireland) governs organizational performance by maximizing the organizations corporate entrepreneurial activity. In particular, the findings suggest that increases in corporate entrepreneurship mediated the relationship between dynamism and performance in Slovenia and munificence and performance in Slovenia and the United States. Furthermore, increases in corporate entrepreneurship in terms of renewal mediated the relationship between munificence and performance in Ireland. This suggests that by adapting to environmental dynamism and munificence private sector organizations are instigating a path dependent process that develops, encourages and shapes corporate entrepreneurial activity in sustainable and competitive ways. Our findings also reveal that renewal mediates the relationship between munificence and performance in the public sector. By increasing renewal, organizations are able to more efficiently maximize the munificence - performance relationship in the public sector. Munificence creates the opportunity for the development of renewal by creating an organization that is adaptive and responsive to opportunities within the environment.

These findings extend and enrich the research by indicating that corporate entrepreneurship matters and contributes towards enhancing organizational performance in not only the private sector in Slovenia but also the public sector in Ireland. Beyond advancing current explanation of corporate entrepreneurship that tie dynamism and munificence to organizational performance. Our findings suggest that adapting to dynamism and munificence might represent a more fundamental means for enhancing corporate entrepreneurship, which in turn improves organizational performance not only in the private sector but also in the public sector.

Another contribution of our study is to clarify the conceptual nature and character of the corporate entrepreneurship construct. Drawing on the literature on multi-dimensional constructs, we find that venturing, renewal, innovation, risk taking and proactivity are complementary components of corporate entrepreneurship in the private sector but, independent components of corporate entrepreneurship in the public sector.

\subsection{Implications for practice}

Given that corporate entrepreneurs and senior managers are interested in realizing corporate entrepreneurship's potential (Wolcott, Lippitz 2007), the findings are valuable since they provide a deeper insight into how corporate entrepreneurship enhances performance. First, the need to recognize the importance of the external environment in the pursuit of corporate entrepreneurship in private and public sector organizations. 
Senior managers need effective systems in place that evaluate factors that influence the dynamism (private sector) and munificence (private and public sector) of the environment. These systems should allow senior management to use multiple sources of data to identify and interpret environmental changes and what impact it might have for corporate entrepreneurial activities. Second, organizations need to nurture entrepreneurial activities to fit the opportunities emerging within the external environment. This fit must be engineered by matching the environment and the types entrepreneurial activities been explored. This requires promoting and managing corporate entrepreneurial activities that will generate new enterprise opportunities. Managers need to be cognizant of the fact that the external environment is constantly changing and need to be aware of those changes and their impact on corporate entrepreneurial activities.

\subsection{Limitations and future research}

The current research findings should be evaluated in light of the limitations of this study, each is paired with a suggestion for future research. The findings are robust, in that a number of recommended steps have been taken to ameliorate concerns over informant bias, non-response bias and common method bias. None of these steps suggested any bias. Conventional research practices were followed in measuring the variables and the reliability of all the variables was tested. It is possible, as in any similar research design, that reverse causality provides an alternative explanation. While care was taken to mitigate this problem, it would have been preferable to have multiple respondents in each organizational unit to minimize effects of systematic response bias. Future research should include at least two senior members of the management team to further enhance reliability. In addition, longitudinal and other experimental research designs should be used to further advance the understanding of external environmental characteristics supporting corporate entrepreneurship within the private and public sector.

In limiting the sample we selected public sector companies from Ireland and private sector companies from Slovenia and the United States and not from other countries. The three selected countries have a very different cultural background that may influence on the behavior of employees and consequently enterprises. The United States sample was small relative to the Slovenian sample; yet, the sample was used for validation purposes and was representative; in addition, findings based on Slovenian samples tend to be comparable to other countries as shown in past cross-nationally comparative studies in corporate entrepreneurship (Antoncic, Hisrich 2000, 2001; Antoncic 2007), business ethics (Bucar et al. 2003), and technological innovativeness (Antoncic et al. 2007). Cross-cultural comparisons in future research may further validate the findings of this study.

Private and public sector organizations vary in their goals, objectives, scale and scope. Identifying these differences as well as their causes and implications will enhance the understanding of the impact of various organizational forms on the success of private and public sector corporate entrepreneurship. Further studies on both private and public sector corporate entrepreneurship in other countries are needed to extend the generalizability of their findings, which are based in the United States, Slovenia and Ireland. 
Future research could also devote more attention to exploring and testing other external environmental and internal organizational dimensions and their influence on corporate entrepreneurship. Other mediation relationships, in addition to or in combination with corporate entrepreneurship could also be tested. One example is the impact or mediating role of corporate entrepreneurship on internal organizational dimensions - performance. Additionally the interactions among these dimensions could contribute to the recognition of different opportunities and other methods for addressing them. This study was limited to few environmental factors important for corporate entrepreneurship. Extending this research by exploring the environmental conditions within which entrepreneurs exist, how they function, and why their corporate entrepreneurial activities succeed or fail can provide a deeper understanding of the relationship between private and public sector corporate entrepreneurship.

In summary, similar to other studies examining corporate entrepreneurship effects, aspects of our research design place certain limitations on the extent to which we can have total confidence on the causal interpretation of results. Thus, even as our study is only a first step toward understanding the mediating role of corporate entrepreneurship for external environment effects on performance in the public sector and limited comparable work has been undertaken in the private sector, it represents a first step from which additional research and managerial understanding can be leveraged.

\section{References}

Aldrich, H. E. 1979. Organizations and environments. Eaglewood Cliffs, NJ: Prentice-Hall.

Antoncic, B. 2007. Intrapreneurship: a comparative structural equation modeling study, Industrial Management \& Data Systems 107(3): 309-325. http://dx.doi.org/10.1108/02635570710734244

Antoncic, B.; Hisrich, R. D. 2000. Intrapreneurship modeling in transition economies: a comparison of Slovenia and the United States, Journal of Developmental Entrepreneurship 5(1): 21-40.

Antoncic, B.; Hisrich, R. D. 2001. Intrapreneurship: construct refinement and cross-cultural validation, Journal of Business Venturing 16: 495-527.

http://dx.doi.org/10.1016/S0883-9026(99)00054-3

Antoncic, B.; Prodan, I.; Hisrich, R. D.; Scarlat, C. 2007. Technological innovativeness and firm performance in Slovenia and Romania, Post-Communist Economies 19(3): 285-302.

http://dx.doi.org/10.1080/14631370701503299

Antoncic, B.; Scarlat, C. 2005. Corporate entrepreneurship and organizational performance: a comparison between Slovenia and Romania, in Proceedings of the $6^{\text {th }}$ International Conference of the Faculty of Management Koper. November 2005, Portoroz, Slovenia. Faculty of management, Koper, Slovenia, 71-89.

Austin, J.; Stevenson, H.; Wei-Skillern, J., 2006. Social and commercial entrepreneurship: Same, different or both?, Entrepreneurship Theory and Practice 30(1): 1-22.

http://dx.doi.org/10.1111/j.1540-6520.2006.00107.x

Baron, R. A.; Tang, J. 2011. The role of entrepreneurs in firm-level innovation: joint effects of positive affect, creativity, and environmental dynamism, Journal of Business Venturing 26: 49-60. http://dx.doi.org/10.1016/j.jbusvent.2009.06.002

Baron, R. M.; Kenny, D. A. 1986. The moderator - mediator variable distinction in social psychology research: conceptual, strategic, and statistical considerations, Journal of Personality and Social Psychology 51(6): 1173-1182. http://dx.doi.org/10.1037/0022-3514.51.6.1173 
Barringer, B. R.; Bluedorn, A. C. 1999. The relationship between corporate entrepreneurship and strategic management, Strategic Management Journal 20(5): 421-444.

http://dx.doi.org/10.1002/(SICI)1097-0266(199905)20:5<421::AID-SMJ30>3.0.CO;2-O

Bellone, C.; Goerl G. 1992. Reconciling public sector entrepreneurship and democracy, Public Administration Review 52(2): 130-134. http://dx.doi.org/10.2307/976466

Borins, S. 2001. The challenge of innovating in government. The PricewaterhouseCoopers endowment for the business of government, February 2001.

Bucar, B.; Glas, M.; Hisrich, R. D. 2003. Ethics and entrepreneurs - an international comparative study, Journal of Business Venturing 18(2): 261-281.

http://dx.doi.org/10.1016/S0883-9026(01)00083-0

Burgelman, R. A. 1983. A process model of internal corporate venturing in the diversified major firm, Administrative Science Quarterly 28(2): 223-244. http://dx.doi.org/10.2307/2392619

Carree, M. A.; Thurik, A. R. 2003. The impact of entrepreneurship on economic growth, in Z. J. Acs, D. B. Audretsch (Eds.). Handbook of entrepreneurship research. Boston, MA: Kluwer Academic Publishers, 437-471.

Chesbrough, H. W. 2002. Making sense of corporate venture capital, Harvard Business Review 80: 90-99.

Coakes, S. J.; Steed, L. G. 2001. SPSS: Analysis without anguish: Version 10.0 for Windows. Chichester: Wiley.

Covin, J. G. 1991. Entrepreneurial vs. conservative firms: a comparison of strategies and performance, Journal of Management Studies 25(5): 439-462.

http://dx.doi.org/10.1111/j.1467-6486.1991.tb00763.x

Covin, J. G.; Slevin, D. P. 1986. The development and testing of an organizational-level entrepreneurship scale, in Ronstadt, R. et al. (Eds.). Frontiers of entrepreneurship research. Wellesley, MA: Babson College, 628-639.

Covin, J. G.; Slevin D. P. 1989. Strategic management of small firms in hostile and benign environments, Strategic Management Journal 10(1): 75-87.

http://dx.doi.org/10.1002/smj.4250100107

Covin, J. G.; Slevin D. P. 1991. A conceptual model of entrepreneurship as firm behavior, Entrepreneurship Theory and Practice 16(1): 7-25.

Cummins, R. C. 1972. Leader-member relations as a moderator of the effects of leader behavior and attitude, Personnel Psychology 25: 655-660.

http://dx.doi.org/10.1111/j.1744-6570.1972.tb02308.x

Currie, G.; Humphreys, M.; Ucbasaran, D.; Mcmanus, S. 2008. Entrepreneurial leadership in the English public sector: Paradox or possibility?, Public Administration 86(4): 987-1008.

http://dx.doi.org/10.1111/j.1467-9299.2008.00736.x

Dess, G. G.; Beard, D. W. 1984. Dimensions of organizational task environments, Administrative Science Quarterly 30: 52-73. http://dx.doi.org/10.2307/2393080

Dess G. G.; Ireland R. D.; Zahra S. A.; Floyd S. W.; Janney J. J.; Lane P. J. 2003. Emerging issues in corporate entrepreneurship, Journal of Management 29(3): 351-378.

Evans, M. G. 1985. A Monte Carlo study of the effects of correlated method variance in moderated multiple regression analysis, Organizational Behavior and Human Decision Processes 36: 305-323. http://dx.doi.org/10.1016/0749-5978(85)90002-0

Forster, J.; Graham, P.; Wanna, J. 1996. The new public entrepreneurialism, in J. Wanna, J. Foster, P. Graham (Eds.). Entrepreneurial management in the public sector. Melbourne: Macmillian.

Fredrickson, J. 1986. The strategic decision process and organization structure, Academy of Management Review 11: 280-297. 
Goodale, J. C.; Kuratko, D. F.; Hornsby, J. S.; Covin, J. G. 2010. Operations management and corporate entrepreneurship: the moderating effect of operations control on the antecedents of corporate entrepreneurial activity in relation to innovation performance, Journal of Operations Management 29(1-2): 116-127.

Gorsuch, R. L. 1983. Factor analysis. $2^{\text {nd }}$ ed. Hillsdale, NJ: Lawrence Erlbaum.

Guth, W. D.; Ginsberg, A. 1990. Corporate entrepreneurship, Strategic Management Journal 11(Special Issue): 5-15.

Hambrick, D. C.; Geletkanycz, M.; Fredrickson, J. 1993. Top executive commitment to the status quo: some tests of its determinants, Strategic Management Journal 14: 401-418.

http://dx.doi.org/10.1002/smj.4250140602

Hambrick, D. C.; Finkelstein, S. 1987. Managerial discretion: a bridge between polar views of organizational outcomes, in L. L. Cummings, B. M. Staw (Eds.). Research in organizational behavior. Greenwich, CT: JAI Press, 369-406.

Harrison, D. A.; McLaughlin, M. E.; Caolter, T. M. 1996. Context, cognition, and common method variance: psychometric and verbal protocol evidence, Organizational Behavior and $\mathrm{Hu}$ man Decision Processes 68: 246-261. http://dx.doi.org/10.1006/obhd.1996.0103

Hean T. K.; Nguyen, T. T. M.; Ng Ping, H. 2007. The effects of entrepreneurial orientation and marketing information on the performance of SMEs, Journal of Business Venturing 22: 592-611. http://dx.doi.org/10.1016/j.jbusvent.2006.05.003

Hisrich, R. D.; Peters, M. P.; Shepherd, D. A. 2010. Entrepreneurship. $8^{\text {th }}$ ed. Chicago: McGrawHill/Irwin.

Hitt, M.; Ireland, R. D.; Palia, K. A. 1982. Industrial firms' grand strategy and functional importance: Moderating effects of technology and uncertainty, Academy of Management Journal 25(2): 265-298. http://dx.doi.org/10.2307/255990

Hood, C. 1995. New public management in the 1980s: variations on a theme, Accounting Organizations and Society 20(2-3): 93-109. http://dx.doi.org/10.1016/0361-3682(93)E0001-W

Hornsby, J. S.; Kuratko, D. F.; Shepherd, D. A.; Bott, J. P. 2009. Managers' corporate entrepreneurial actions: examining perception and position, Journal of Business Venturing 24: 236-247. http://dx.doi.org/10.1016/j.jbusvent.2008.03.002

Hornsby, J. S.; Kuratko, D. F.; Zahra, S. 2002. Middle managers' perception of the internal environment for corporate entrepreneurship: assessing a measurement scale, Journal of Business Venturing 17(3): 253-273. http://dx.doi.org/10.1016/S0883-9026(00)00059-8

Huber, G. P.; Power, D. 1985. Retrospective reports of strategic-level managers: guidelines for increasing their accuracy, Strategic Management Journal 6: 171-180.

http://dx.doi.org/10.1002/smj.4250060206

IPA. 2007. Irish Public Administration $41^{\text {st }}$ Edition Administration. Yearbook and Diary.

Ireland, D. R.; Covin, J. G.; Kuratko, D.F. 2009. Conceptualizing corporate entrepreneurship strategy, Entrepreneurship Theory and Practice 33(1): 19-46.

http://dx.doi.org/10.1111/j.1540-6520.2008.00279.x

Kanter, R. M. 1984. The change masters. New York, NY: Touchstone, Simon and Schuster.

Kearney, C.; Hisrich, R. D.; Roche, F. 2007. Facilitating public sector corporate entrepreneurship process: a conceptual model, Journal of Enterprising Culture 15(3): 275-299. http://dx.doi. org/10.1142/S0218495807000150

Kearney, C.; Hisrich, R. D.; Roche, F. 2009. Public and private sector entrepreneurship: similarities, differences or a combination?, Journal of Small Business and Enterprise Development 16(1): 26-46. http://dx.doi.org/10.1108/14626000910932863

Kearney, C.; Hisrich, R. D.; Roche, F.W. 2010. Change management through entrepreneurship in public sector enterprises, Journal of Developmental Entrepreneurship 15(4): 1-23. http://dx.doi. org/10.1142/S1084946710001646 
Keats, B.; Hitt, M. 1988. A casual model of linkages among environmental dimensions, macro organizational characteristics, and performance, Academy of Management Journal 31: 570-598. http://dx.doi.org/10.2307/256460

Kelley, D. A.; Peters, L.; O'Connor Colarelli, G. 2009. Intra-organizational networking for innovation-based corporate entrepreneurship, Journal of Business Venturing 24: 221-235.

http://dx.doi.org/10.1016/j.jbusvent.2008.05.010

Khandwalla, P. N. 1987. Generators of pioneering-innovative management. Some Indian evidence, Organizational Studies 8(1): 39-59. http://dx.doi.org/10.1177/017084068700800104

Kirzner, I. M. 1997. Entrepreneurial discovery and the competitive market process: an Austrian approach, Journal of Economic Literature 35(3): 60-85.

Kline, P. 2000. The handbook of psychology testing. $2^{\text {nd }}$ ed. London: Routledge.

Lindell, M. K.; Whitney, D. J. 2001. Accounting for common method variance in cross-sectional research designs, Journal of Applied Psychology 86: 114-121.

http://dx.doi.org/10.1037/0021-9010.86.1.114

Linden, R. 1990. From vision to reality: strategies of successful innovators in government. Charlottesville, SC: LEL Enterprises.

Luke, B.; Verreynne, M. L.; Kearins, K. 2010. Innovation and entrepreneurial activity in the public sector: the changing face of public sector institutions, Innovation: Management, Policy and Practice 12(2): 138-153. http://dx.doi.org/10.5172/impp.12.2.138

Lumpkin, G. T.; Dess, G. G. 1996. Clarifying the entrepreneurial orientation construct and linking it to performance, Academy of Management Review 12(1): 135-172.

Miller, D. 1983. The correlates of entrepreneurship in three types of firms, Management Science 29: 770-791. http://dx.doi.org/10.1287/mnsc.29.7.770

Miller, D.; Friesen, P. H. 1978. Archetypes of strategy formulation, Management Science 24: 921-933. http://dx.doi.org/10.1287/mnsc.24.9.921

Miller, K. D. 2007. Risk and rationality in entrepreneurial processes, Strategic Entrepreneurship Journal 1: 57-74. http://dx.doi.org/10.1002/sej.2

Minniti, M. 2008. The role of government policy on entrepreneurial activity: productive, unproductive, or destructive, Entrepreneurship Theory and Practice 32(5): 779-790.

http://dx.doi.org/10.1111/j.1540-6520.2008.00255.x

Minniti, M.; Levesque, M. 2010. Entrepreneurial types and economic growth, Journal of Business Venturing 25: 305-314. http://dx.doi.org/10.1016/j.jbusvent.2008.10.002

Morris, M. H. 2006. Sustainability and the Non-profit Enterprise. Unpublished Questionnaire.

Morris, M. H.; Jones, F. F. 1999. Entrepreneurship in established organizations: the case of the public sector, Entrepreneurship Theory and Practice 24(1): 71-91.

Morris, M. H.; Kuratko, D. F.; Covin, J.G. 2008. Corporate entrepreneurship and innovation. Mason, OH: Thomson/South-Western.

Narayanan, V.; Yang, Y.; Zahra, S. 2009. Corporate venturing and value creation: a review and proposed framework, Research Policy 38(1): 58-76. http://dx.doi.org/10.1016/j.respol.2008.08.015

Nutt, P. C. 2005. Comparing public and private sector decision-making practices, Journal of Public Administration Research and Theory 30: 1-30.

Osborne, D; Gaebler, T. A. 1992. Reinventing government: how the entrepreneurial spirit is transforming the public sector. Reading, MA: Addison-Wesley.

Pinchot, G. 1985. Intrapreneuring. New York: Harper and Row.

Powell, T. C. 1992. Organizational alignment as competitive advantage, Strategic Management Journal 13: 119-134. http://dx.doi.org/10.1002/smj.4250130204

Ramamurti, R. 1986. Public entrepreneurs: who they are and how they operate, California Management Review 28(3): 142-158. http://dx.doi.org/10.2307/41165207 
Robinson, R. B; Pearce, J. A. 1988. Planned patterns of strategic behavior and their relationship to business-unit performance, Strategic Management Journal 9(1): 43-60.

http://dx.doi.org/10.1002/smj.4250090105

Romzek, B.; Dubnick, M. 1994. Issues of accountability in flexible personnel systems, in P. Ingraham, B. Romzek (Eds.). New paradigms for government: issues for the changing public service. San Francisco: Jossey-Bass.

Russell, R. D. 1999. Developing a process model of intrapreneurial systems: a cognition mapping approach, Entrepreneurship Theory and Practice 23(3): 65-85.

Schumpeter, J. A. 1934. The theory of economic development. Cambridge, MA: Harvard University Press.

Sharfman, M. P.; Wolf, G.; Chase, R. B.; Tansik, D. A. 1988. Antecedents of organizational slack, Academy of Management Review 4: 601-614.

Sharma, P.; Chrisman, J. J. 1999. Toward a reconciliation of the definitional issues in the field of corporate entrepreneurship, Entrepreneurship Theory and Practice 23(3): 11-27.

Simsek, Z.; Veiga, J. F.; Lubatkin, M. H. 2007. The impact of managerial environmental perceptions on corporate entrepreneurship: towards understanding discretionary slack's pivotal role, Journal of Management Studies 44(8): 1398-1424.

Spector, P. E. 2006. Methods variance in organizational research: truth or urban legend?, Organizational Research Methods 9(2): 221-232. http://dx.doi.org/10.1177/1094428105284955

Stopford, J. M.; Baden-Fuller, C. W. F. 1994. Creating corporate entrepreneurship, Strategic Management Journal 15: 521-536. http://dx.doi.org/10.1002/smj.4250150703

Stranks, J. 2005. Stress at work. Burlington, MA: Elsevier Butterworth-Heinemann.

Teng, B. 2007. Corporate entrepreneurship activities through strategic alliances: a resource-based approach toward competitive advantage, Journal of Management Studies 44(1): 119-142.

Thompson, J.; Doherty, B. 2006. The diverse world of social enterprise: a collection of social enterprise stories, International Journal of Social Economics 33(5/6): 399-410.

http://dx.doi.org/10.1108/03068290610660643

Timmons, J. A. 1994. New venture creation: entrepreneurship in the $21^{\text {st }}$ century. Burr Ridge, Ill.: Irwin.

Wenneker, S.; Thurik, R. 1999. Linking entrepreneurship and economic growth, Small Business Economics 13: 27-55. http://dx.doi.org/10.1023/A:1008063200484

Wolcott R. C.; Lippitz, M. J. 2007. The four models of corporate entrepreneurship, MIT Sloan Management Review 49(1): 75-82.

Zahra S. A. 1996. Governance, ownership, and corporate entrepreneurship: the moderating impact of industry technological opportunities, Academy of Management Journal 39(6): 1713-1735. http://dx.doi.org/10.2307/257076

Zahra, S. A. 1991. Predictors and financial outcomes of corporate entrepreneurship: an exploratory study, Journal of Business Venturing 6(4): 259-285.

http://dx.doi.org/10.1016/0883-9026(91)90019-A

Zahra, S. A. 1993. Environment, corporate entrepreneurship, and financial performance: a taxonomic approach, Journal of Business Venturing 8(4): 319-340.

http://dx.doi.org/10.1016/0883-9026(93)90003-N

Zahra, S. A.; Covin, J. G. 1995. Contextual influences on the corporate entrepreneurship performance relationship: a longitudinal analysis, Journal of Business Venturing 10(1): 43-58.

http://dx.doi.org/10.1016/0883-9026(94)00004-E

Zahra, S. A.; Zahra, P. H. 1992. Organizational structure and corporate entrepreneurship, in The Academy of Management Conference, Las Vegas, NV, August 9-12, 1992. 
Claudine KEARNEY, PhD lectures and researches at University College Dublin. Dr. Kearney received her M.B.S. and Ph.D. degrees from the UCD Michael Smurfit Graduate Business School and her Post-Doctoral Fellowship from Thunderbird School of Global Management. Her research pursuits focus on entrepreneurship and innovation, with special interests in antecedents and outcomes of corporate entrepreneurship in private and public sector organizations; strategic entrepreneurship and innovation in SMEs and large corporations; the emergence of entrepreneurship in SMEs. She serves on editorial boards, published journal articles, books, book chapters and conference papers.

Robert D. HISRICH, PhD, is the Garvin Professor of Global Entrepreneurship and Director of the Walker Center for Global Entrepreneurship at Thunderbird School of Global Management, the world's leading school of global business. Dr. Hisrich received his BA from DePauw University, his MBA and Ph.D. from the University of Cincinnati, and honorary doctorate degrees from Chuvash State University (Russia) and the University of Miskolc (Hungary). Dr. Hisrich has authored or co-authored 25 books and written more than 300 articles on entrepreneurship, international business management and venture capital.

Bostjan ANTONCIC, PhD, is Professor of Entrepreneurship at the Faculty of Economics, University of Ljubljana, Slovenia. Dr. Antoncic received his B.Sc. and M.Sc. from University of Ljubljana and Ph.D. from the Case Western Reserve University. His main research interests include corporate entrepreneurship, entrepreneurial networks, entrepreneurial personality and international entrepreneurship. He has authored or co-authored fourteen books (eleven of them in the area of entrepreneurship) and numerous scientific research articles. His papers were published in various academic journals. 